\title{
Using Meiobenthic Species as a Measure of the Impact of Acid Mine Outflows on the Tioga River in North Central Pennsylvania
}

\author{
Carissa Ganong ${ }^{\dagger}$ and Gregory Carson ${ }^{\S}$ \\ Department of Chemistry and Physics \\ Mansfield University \\ Mansfield, Pennsylvania 16933 USA \\ John Kirby \\ Department of Biology \\ Mansfield University \\ Mansfield, Pennsylvania 16933 USA
}

Received: April 3, $2007 \quad$ Accepted: August 8, 2007

\begin{abstract}
In this study meiobenthic communities were sampled from several acid mine drainage (AMD) impacted sites along the Tioga River in North Central Pennsylvania. Concentrations of several chemical indicators of aquatic health $\left(\mathrm{Fe}^{+2} / \mathrm{Fe}^{+3}, \mathrm{Mn}^{+2}\right.$, and $\left.\mathrm{SO}_{4}{ }^{-2}\right)$ were measured along with the $\mathrm{pH}$. Meiobenthic communities were present at all AMD impacted locations but diversity and abundance varied. The diversity and abundance at the AMD impacted sites was inversely related to the concentration of several key acid mine drainage indicators. Macroinvertebrate species were collected only at the unimpacted head waters of the Tioga River. All other sampled locations were devoid of macroinvertebrate species.
\end{abstract}

\section{INTRODUCTION}

During the past century coal mining in the Appalachian region has contaminated streams with acidic and metallic sediments. The Tioga River, located in Tioga County, Pennsylvania, is situated atop the extreme Northeastern margins of the Appalachian bituminous coal beds. During the early 1900 's several strip mines were operated on the outskirts of the town of Blossburg. Presently, tributaries draining the abandoned strip mine areas deposit large amounts of manganese, iron, and acidity into the Tioga River.

Acid mine drainage (AMD) is a

† Carrisa is now a graduate student in the Biology Department of Central Arkansas University.

$\S$ Corresponding author. serious problem in many parts of the world, typically in areas where extensive coal mining has occurred [1]. The main sources of AMD are pyrite and marcasite, two common iron (II) sulfide minerals, which are found in large amounts in mine tailings. When these minerals are exposed to air, the following reaction occurs:

$$
\begin{aligned}
4 \mathrm{FeS}_{2}+15 \mathrm{O}_{2}+14 \mathrm{H}_{2} \mathrm{O} \rightarrow & 4 \mathrm{Fe}(\mathrm{OH})_{3} \\
& +16 \mathrm{H}^{+}+8 \mathrm{SO}_{4}{ }^{-2}
\end{aligned}
$$

In this reaction, both iron and sulfur are oxidized: iron (II) becomes iron (III), while the sulfide ion is oxidized to form sulfate and then sulfuric acid. These reactions are both detrimental to the environment. Sulfuric acid, an extremely strong acid, quickly dissociates in water, lowering the $\mathrm{pH}$ to levels that endanger 
aquatic life and render the water unsuitable for many human uses [2]. The iron (III) cation easily reacts with water to form iron (III) hydroxide, an insoluble reddish or yellowish material that coats stream beds and is commonly referred to as "yellow dog" or "yellow boy" [3].

The sulfuric acid produced by the oxidation of iron pyrite may further react with other minerals and may release other heavy metals (such as manganese) into the water $[1,2]$. In addition to the leaching of manganese from other minerals present at AMD locations, manganese containing pyrites, like iron pyrites, can undergo an oxidation process producing manganese (II).

$$
2 \mathrm{MnS}_{2}+7 \mathrm{O}_{2}+2 \mathrm{H}_{2} \mathrm{O} \rightarrow 2 \mathrm{Mn}^{+2}+4 \mathrm{SO}_{4}^{-2}+4 \mathrm{H}^{+}
$$

AMD has a severe environmental impact not only during ongoing coal mining, but also for several decades after mines are abandoned. It is estimated that drainage from coal mines contributes about 8 million tons of sulfuric acid annually to rivers and streams. Only a fraction of this is neutralized by the natural alkalinity of the waters [3]. This vast amount of pollution is difficult to contain because of the expense and effort involved in sealing off abandoned mines [1]. In some areas, efforts have been made to neutralize acidified streams via limestone catch basins, but this technique is also expensive and time-intensive.

Quantification of AMD damage has been an active area of research for many years. Stream chemistry has been commonly used as a measure of pollution, and more recently biotic indices have been developed. Indices focusing on macroinvertebrates and fish are still the most frequently used by state monitoring agencies. However, macroinvertebrates and fish cannot tolerate the conditions of the most severely AMD-impacted streams. In these cases, biotic indices based on benthic organisms, which are more tolerant of the harsh conditions, have proved extremely useful. Many of these indices focus on algae, specifically diatoms [4-6].

\section{PURPOSE}

The purpose of this study was to identify and compare the meiobenthic communities and macroininvertebrate species at three AMD impacted sites. A fourth site, which receives no AMD, was used as a control. Concentrations of $\mathrm{Mn}^{+2}$, $\mathrm{SO}_{4}{ }^{-2}$, along with the total iron concentration were measured as well as the $\mathrm{pH}$ at each of the four locations. The ultimate objective was to determine if meiobenthic measurements are an improvement over the use of macroinvertebrate measurements in determining the severity of AMD impact.

\section{METHODOLOGY AND PROCEDURES}

We selected four sites near Blossburg, Pennsylvania. Our first site, Coal Creek, is a pool immediately outside an abandoned horizontal mineshaft; the pool is fed year-round by outflow from the mineshaft. Old 99, our second site, is a stream flowing from another abandoned mineshaft with year-round outflow. Our third site, Fall Brook, is a stream near Old 99 and is contaminated by AMD. The Tioga River at County Bridge, our final site, is located above the mined areas and is unpolluted by AMD and served as a control site. Mineralogy is the same at each site: scattered deposits of pyrite, hematite, goethite, and marcasite in areas of mainly shale and sandstone [7]. Samples were collected at 1 month intervals from the Spring of 2003 through the Spring of 2006. Each chemical measurement was performed on-site.

The total iron concentration was measured using a Hach spectrophotometer using the phenanthroline method measuring the absorbance at $510 \mathrm{~nm}$. The phenanthroline method converts all iron (soluble, insoluble, and $\mathrm{Fe}^{+3}$ ) into $\mathrm{Fe}^{+2}$. We did not distinguish between $\mathrm{Fe}^{+2}$ and $\mathrm{Fe}^{+3}$ species in this study. The limit of detection of this method for total iron concentration is $0.04 \mathrm{mg} / \mathrm{L}$ with a standard deviation of \pm $0.027 \mathrm{mg} / \mathrm{L}$ [8]. The manganese $\left(\mathrm{Mn}^{+2}\right)$ concentration was also measured using a 


\begin{tabular}{|c|c|c|c|c|}
\hline Site & Coal Creek & Old 99 & Fall Brook & County Bridge \\
\hline $\mathbf{p H}$ & $2.05 \pm 0.63$ & $2.40 \pm 0.00$ & $3.54 \pm 0.04$ & $6.55 \pm 0.35$ \\
\hline Total Iron & $27.15 \pm 3.4$ & $0.96 \pm 0.25$ & $0.3 \pm 0.13$ & $0.05 \pm 0.026$ \\
\hline $\mathbf{M n}^{+2}$ & $7.56 \pm 0.64$ & $10.67 \pm 5.3$ & $0.89 \pm 0.37$ & $0.26 \pm 0.25$ \\
\hline SO$_{4}{ }^{2-}$ & $550 \pm 30$ & $350 \pm 80$ & $45 \pm 30$ & $27 \pm 21$ \\
\hline
\end{tabular}

Table 1. Water Chemistry Results (mean concentrations in ppm).

Hach spectrophotometer using the periodate method measuring the absorbance at 548 $\mathrm{nm}$. The limit of detection of this method for $\mathrm{Mn}^{+2}$ concentrations is $0.12 \mathrm{mg} / \mathrm{L}$ with a standard deviation of $\pm 0.18 \mathrm{mg} / \mathrm{L}$ [8]. The sulfate $\left(\mathrm{SO}_{4}^{-2}\right)$ concentration was also measured using a Hach spectrophotometer using the turbidimetric method measuring the absorbance at $420 \mathrm{~nm}$. The limit of detection of this method for sulfate concentration is $4.9 \mathrm{mg} / \mathrm{L}$ with a standard deviation of $\pm 0.5 \mathrm{mg} / \mathrm{L}$ [8]. The $\mathrm{pH}$ was measured with a Hanna $\mathrm{pH}$ meter.

Aquatic meiobenthic organisms were collected by grab samples. Grab samples were collected once at each location using a Gladware container to scoop up the substrate. The container penetrated approximately $2 \mathrm{~cm}$ into the substrate. A half a cup of sediment and two cups of water were collected during each sampling. The sediment collected came from an undisturbed area at each location. The substrate consisted of flat cobble with fine silt and sandstone. The samples were returned to the lab and examined using a compound microscope. When possible, photographs of the organisms were taken using a camera attached to a compound microscope.

Macroinvertebrate species were collected via 1-minute kick samples. Samples were collected at the same locations as the grab samples. The kick samples were collected by placing a net across the sampling area and disturbing the substrate by kicking for one minute upstream from the net opening. The samples that were collected were then examined back in the laboratory. One kick sample was collected at each location.

\section{RESULTS}

\section{a. Water Chemistry}

Table 1 summarizes the chemical indicators of AMD at all four locations. The ion concentrations (expressed as parts per million) and $\mathrm{pH}$ data reported below are averages of the measurements at each location.

\section{b. Meiobenthic and Macroinvertebrate Organisms}

Tables 2 through 4 summarize the meiobenthic communities sampled at the three AMD impacted locations. Table 5 summarizes the meiobenthic community sampled at the control site. Table 6 summarizes the macroinvertebrate species that were collected at the control site. No macroinvertebrate species were found at any of the AMD impacted locations.

\section{DISCUSSION}

\section{a. Water Chemistry}

We predicted that the mineshaft outflows (Coal Creek and Old 99) would have the lowest pHs and the highest levels of iron and sulfate, since these ions are byproducts of the oxidation of pyrite and marcasite. These predictions were true: both mineshaft outflow sites had extremely low pHs, as would be expected if sulfate (and hence sulfuric acid) concentrations were high. The $\mathrm{pH}$ of Fall Brook, also as expected, is lowered as it is located near the Old 99 outflow. The control location, County 


\begin{tabular}{|c|l|l|}
\hline \multicolumn{1}{|c|}{ Algae } & \multicolumn{1}{|c|}{ Protista } & \multicolumn{1}{c|}{ Animals } \\
\hline Klebsormidiophyceae & Ciliophora & Nematoda (O) \\
Klebsormidium (VA) & Stylonichia (C) & Tardigrada (O) \\
Eaplotes (C) & Rotifera \\
Eunotia spp. (VA) & Aspidisca (O) & Cephalodella (O) \\
Pinnularia (A) & Uroleptus (O) & \\
Euglenophyceae & & \\
Euglena (C) & & \\
\hline
\end{tabular}

Table 2. Meiobenthic Community of Coal Creek. VA is Very abundant ( $>200 / c c) ; A$ is Abundant (50-199/cc); C is Common (10-49/cc); and O is Occasional (1-9/cc).

\begin{tabular}{|l|l|l|}
\hline \multicolumn{1}{|c|}{ Algae } & \multicolumn{1}{|c|}{ Animals } & \multicolumn{1}{c|}{ Fungi } \\
\hline $\begin{array}{l}\text { Entransia (VA) } \\
\text { Eunotia (A) }\end{array}$ & $\begin{array}{l}\text { Rotifera } \\
\text { Lecane }(\mathrm{O}) \\
\text { Cephalodella (O) }\end{array}$ & Fungi imperfecti (VA) \\
\hline
\end{tabular}

Table 3. Meiobenthic Community of Old 99 . VA is Very abundant ( $>200 / c c)$; A is Abundant (50 $-199 / \mathrm{cc}$ ); $\mathrm{C}$ is Common (10-49/cc); O is Occasional (1-9/cc).

Bridge, which is unimpacted by AMD, had a $\mathrm{pH}$ close to neutral.

Both Coal Creek and Old 99 had high concentrations of sulfate as described above. The sulfate level at Fall Brook was lower than both of those at Coal Creek and Old 99. This decrease in sulfate concentration correlates nicely with the increase in $\mathrm{pH}$ at Fall Brook (less sulfate, less sulfuric acid, higher pH's). The sulfate concentration at County Bridge also agrees with our $\mathrm{pH}$ measurements.

It should be noted that although both Coal Creek and Old 99 had low pH and high sulfate concentrations, Old 99 had a dramatically lower total iron concentration than Coal Creek. However, Old 99 did have a higher manganese concentration compared to Coal Creek. The high manganese level at Old 99 suggests that manganese (instead of iron) sulfide may have been predominant at that site. The concentration of manganese at Fall Brook was also determined to be higher than the iron concentration. This makes sense since the Old 99 outflow is located near Fall Brook. The concentration of manganese at County Bridge is negligible compared to the three other locations.

\begin{tabular}{|l|}
\hline \multicolumn{1}{|c|}{ Algae } \\
\hline Bacillariophyceae \\
Eunotia (A) \\
Pinnularia (C) \\
Euglenophyceae \\
Trachelomonas (A) \\
Volvocaceae \\
Pandorina (O) \\
Chlamydomonads (A) \\
\hline
\end{tabular}

Table 4. Meiobenthic Community of Fall Brook. A is Abundant (50-199/cc); $C$ is Common (10 - 49/cc); O is Occasional (1 9/cc)

b. Meiobenthic Organisms

The meiobenthic organisms at all three AMD sites are of necessity acidophiles, and some are extremely tolerant to high metal concentrations, such as the alga Klebsormidium (= Hormidium) which is sometimes used as an indicator of high iron concentrations [6]. Species of the genus Eunotia also have been found to be 


\begin{tabular}{|l|l|l|}
\hline \multicolumn{1}{|c|}{ Algae } & \multicolumn{1}{|c|}{ Protista } & \multicolumn{1}{c|}{ Animals } \\
\hline Bacillariophyceae & Ciliophora & Nematoda (O) \\
Synedra (C) & Urostyla (O) & Rotifera \\
Fragillaria (A) & Cephalodella (O) \\
Navicula (A) & Saprophilus (O) & \\
Pinnularia (C) & Pleuronema (O) & \\
Euglenophyceae & Kahlia (O) & \\
Trachelomonas (A) & & \\
Desmidiaceae & & \\
Closterium (O) & & \\
Euastrum (O) & & \\
\hline
\end{tabular}

Table 5. Meiobenthic Community of County Bridge. VA is Very abundant (>200/cc); A is Abundant (50 - 199/cc); C is Common (10 - 49/cc); and O is Occasional (1-9/cc).

acid tolerant $[9,10]$, and were located at all AMD impacted sites in our study.

Of all AMD impacted sites, species diversity and abundance were highest at Coal Creek (Table 2). We were unable to numerically estimate the abundance of Klebsormidium, a highly filamentous alga that attaches to substrate; however, it was very abundant (VA) and located only at Coal Creek, the location with the highest iron content in our study.

The meiobenthic community at Old 99 (Table 3) had fewer species and a lower abundance of those species present than Coal Creek. We were unable to determine exact numbers of Entransia, another filamentous alga that attaches to substrate, so we again refer to it as very abundant (VA). The fungi imperfecti were parasites on Entransia. Since Entransia was referred to as very abundant (VA), we also classified the fungal parasites as very abundant (VA), as it was difficult to assess the abundance of these organisms.

Fall Brook had the lowest species richness and the lowest abundance of those species out of all the locations we studied. Only algae were found at this location (Table 4). The population of Trachelomonas and chlamydomonads were abundant (A). County Bridge, the control site unimpacted by AMD, had the highest species richness of all four locations (Table 5).

\section{c. Macroinvertebrate Organisms}

Of all the sites surveyed in this study, only County Bridge, the unimpacted control site had any population of macroinvertebrates (Table 6). Six (6) orders were represented comprised of 13 genera representing 82 individual insects.

\section{CONCLUSIONS}

With the exception of our control site, all locations surveyed were impacted by AMD. As such, the concentrations of total iron (the sum of $\mathrm{Fe}^{+2}$ and $\mathrm{Fe}^{+3}$ present) and sulfate were elevated, as one would expect given the chemistry behind of AMD. Accordingly, the $\mathrm{pH}$ measured at each of the three AMD impacted areas was dramatically lower than at the control location. The increased concentration of manganese at Coal Creek and Old 99 locations should be investigated further. At this time, it is unclear as to whether the increased manganese concentration is due to the leaching of manganese from other manganese-containing minerals in the area or from the direct oxidation of manganesecontaining pyrites.

In an effort to quantify the damage done to several AMD impacted sites, several surprising findings emerged in addition to some not so surprising findings. As expected, macroinvertebrates were good indicators of the chemical and biological health of the control location of our study, which was unimpacted by AMD. At the three locations that were impacted by AMD, the severity of AMD impact reached a point where no macroinvertebrates could survive. The lack of macroinvertebrate species at the AMD impacted locations showed that 


\begin{tabular}{|l|l|c|l|}
\hline Order & Genus & Quantity & Functional Group \\
\hline Ephemeroptera & Epeorus & 10 & Collector/Gatherer \\
\hline Ephemeroptera & Stenonema & 2 & Collector/Gatherer \\
\hline Ephemeroptera & Rhithrogena & 1 & Collector/Gatherer \\
\hline Ephemeroptera & Cinygmula & 1 & Collector/Gatherer \\
\hline Odonata & Octogomphus & 1 & Predator \\
\hline Odonata & Ariogomphus & 1 & Predator \\
\hline Plecoptera & Leuctra & 1 & Shredder \\
\hline Plecoptera & Beloneuria & 1 & Predator \\
\hline Megaloptera & Nigronia & 2 & Predator \\
\hline Trichoptera & Dolophilodes & 57 & Collector/Filterer \\
\hline Trichoptera & Hydropsyche & 3 & Collector/Filterer \\
\hline Diptera & Antocha & 1 & Collector/Gatherer \\
\hline Diptera & Dicranota & 1 & Predator \\
\hline Total Macroinvertebrate Population: 82 & & \\
\hline
\end{tabular}

Table 6. Aquatic Macroinvertebrate Composition of County Bridge.

macroinvertebrate diversity and population would not be helpful in our determination of the severity of impact of AMD on our locations. Instead, our study showed that algae, which are known to be more tolerant of harsh AMD conditions, may be a better indicator of the health of AMD impacted areas. Even the most impacted site in our study showed a difference in diversity of algae types and abundance. However, our study also shows that total algae diversity and abundance needs to be carefully interpreted. The most impacted site (based on chemical components) had the largest abundance and species richness of all impacted sites studied while the least impacted site (again based on chemical components) showed the least amount of species richness and abundance.

Our study shows that for the three locations studied, the alga Eunotia is the single best indicator of the overall health of these AMD impacted locations. It should be noted that filamentous species of algae could be used as indicators of overall AMD impact if their numbers were not so difficult to quantify and if they were present at all locations. Eunotia, however, was present at all three AMD impacted sites and not at the control location, and its numbers were less difficult to count. Its abundance also correlated well with overall $\mathrm{pH}$ measurements (the lower the $\mathrm{pH}$ the more Eunotia) as well as with the overall cation and anion concentrations (high iron and sulfate gave the highest abundance of Eunotia). Several other AMD impacted locations are currently being studied to determine if the trends we discovered using Eunotia as an indicator of AMD impact are more widely applicable.

\section{ACKNOWLEDGEMENTS}

The authors of this paper would like to acknowledge Michael Malick, Craig Oppel, and Ryan Sweater for their work in collecting the macroinvertebrate species at County Bridge. The authors would also like to acknowledge the Mansfield University Faculty Professional Development Committee for the funds provided which supported this undergraduate research project. 


\section{REFERENCES}

1. Spiro, T., and W. Stigliani, Chemistry of the Environment (2nd ed.), (Prentice Hall: Upper Saddle River, New Jersey, 2003).

2. Gymer, R. G., Chemistry in the Natural World, D.C. Heath \& Co.: (Lexington, Massachusetts, 1977).

3. Hill, B., Herlihy, A., Kaufmann, P., Stevenson, R., McCormick, F., Johnson, C., "Use of periphyton assemblage data as an index of biotic integrity," Journal of the North American Benthological Society, 19(1): 50-67, (2000).

4. Hill, B., Stevenson, R., Pan, Y., Herlihy A., Kaufman, P., and Johnson, C., "Comparison of correlations between environmental characteristics and stream diatom assemblages characterized at genus and species level," Journal of the North America Benthological Society 20(2): 299-310, (2001).

5. Sabater, S., Buchaca, T., Cambra, J., Catalan, J., Guasch, H., Ivorra, N., Muñoz, I., Navarro, E., Real, A., and Romaní, M., "Structure and function of benthic algal communities in an extremely acid river," Journal of Phycology, 39: 481-489, (2003).
6. Stevens, A. E., McCarthy, B.C., and Vis, M.L., Metal content of Klebsormidium dominated (Chlorophyta) algal mats from acid mine drainage waters in southeastern Ohio, Journal of the Torrey Botanical Society 128(3): 226-233, (2001).

7. Barnes, J. H., Rocks and Minerals of Pennsylvania, (Commonwealth of Pennsylvania Department of Conservation and Natural Resources Bureau of Topographic and Geologic Survey, 2004).

8. Hach DR/890 Colorimeter Procedures Manual (Hach Company, 1997-2000).

9. Patrick, R., Ecology of freshwater diatoms and diatom communities, $D$. Werner, ed. The Biology of Diatoms. Botanical Monographs, Vol. 13. (Blackwell Scientific Publications, Oxford, England, 1977).

10. Verb, R., and Vis, M, "Comparison of benthic diatom assemblages from streams draining abandoned and reclaimed coal mines and nonimpacted sites," Journal of the North American Benthological Society, 19(2): 274-288, (2000).

\section{MANSFIELD U N I V E R S I T Y Developing Tomorrow's Leaders}

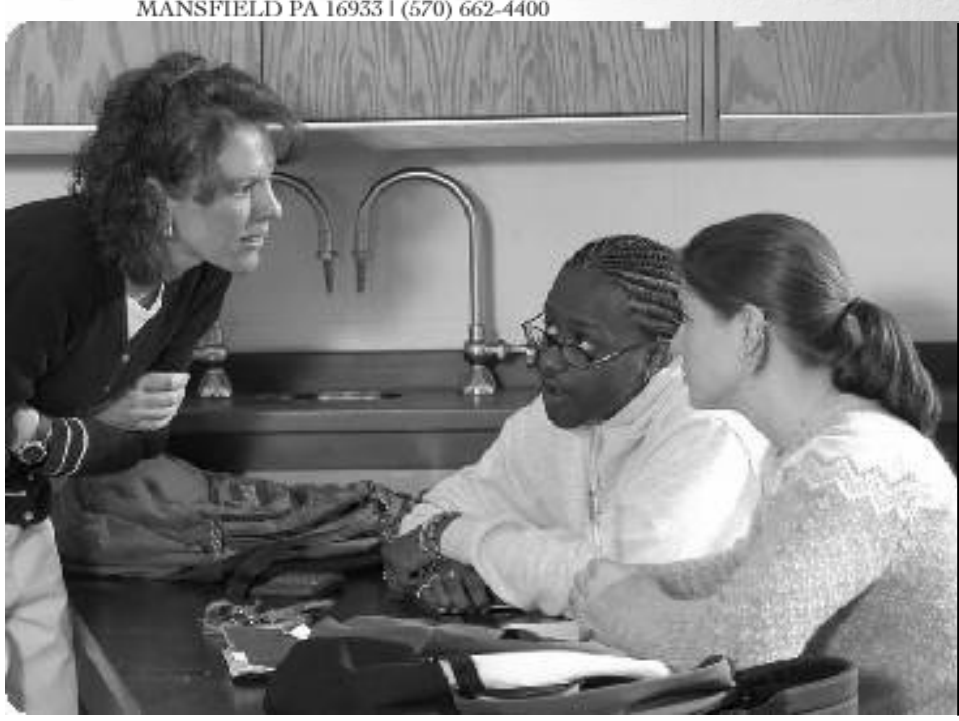

Most classes at Mansfield are small. With a Faculty to Student Ratio of 17:1.

You'll get to know your instructors by name and they'll know you -a great thing when you need extra help!

Most classes are held in the buildings on the upper end of the campus, but you might also have a class or lab in Pinecrest, South Hall or even a dining etiquette course in Manser.

Overall, you'll find a relaxed, friendly environment for learning at Mansfield.

Class work can be demanding, but there's always someone here to heln vou succeed. 


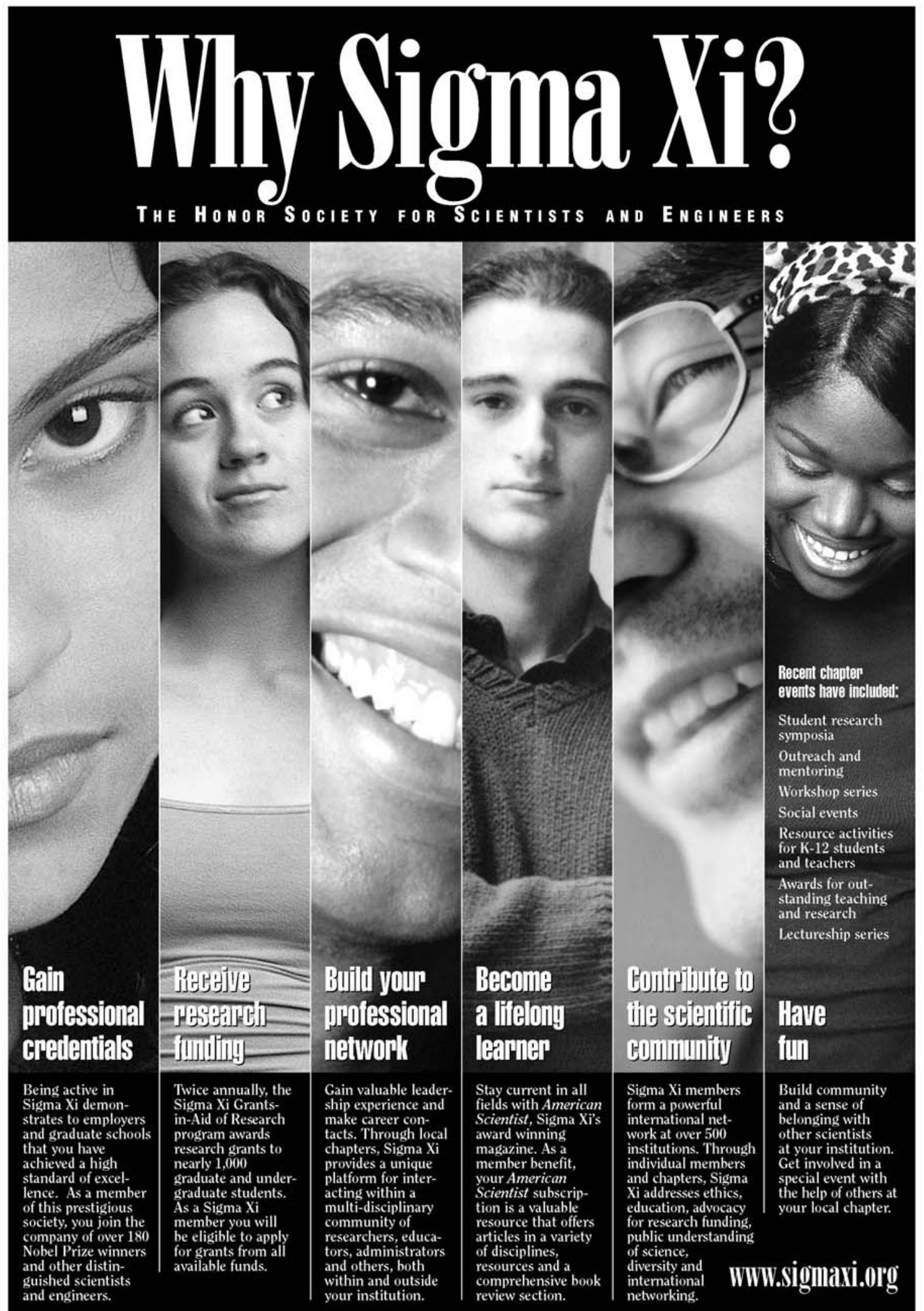

Sigma Xi, The Scientific Research Society • 89 Alexanter Drive • P.O. Box 13975 • Research Triangle Park, NC 27709 • 819-549-4691 • 800-243-6534 